\title{
The perceptions and attitudes of adolescent street girls on the use of traditional medicine and commercial sex work in Harare Central Business District
}

\author{
Witness Chikoko \\ Department of Social Work, \\ University of Zimbabwe \\ wchikoko@gmail.com, \\ Victor. N. Muzvidziwa \\ Midlands State University, \\ Watch Ruparanganda \\ Department of Sociology \\ University of Zimbabwe, \\ $\&$ \\ The late Emelia Chikoko \\ Social Worker \\ Department of Social Services \\ Ministry of Public Services Labour and Social Welfare.
}

\begin{abstract}
The paper argues that there is a close relationship between use of traditional medicine and commercial sex work among adolescent street girls in Harare Central Business District. As a result of using the traditional medicine one could argue that this demonstrates agency of these young adults. The agency is demonstrated when these adolescent girls use the medicine to facilitate commercial sex work. On the other hand one could argue that, use of traditional medicine in commercial sex work illustrates huge rights violations prevalent on the streets of Harare Central Business District. The behaviours associated with commercial sex work and use of traditional medicine could be viewed as contravening some provisions of the United Nations Convention on the Rights of a Child (UNCRC) (1989), African Charter on the Rights and Welfare of Children (ACRWC) (1999). Included are violations of some of the national child rights laws and policies such as the Children's Act (5.06), Criminal Law (Codification and Reform) Act (9.23) and the National Action Plan for Orphans and
\end{abstract}


Other Vulnerable Children (NAP for OVCs) (2011-2015). This study is part of the researcher's doctoral study which used street ethnography and qualitative research methodology.

Key Words: Child Rights, Child Agency, Traditional Medicine, Street Girls

\section{Introduction}

This article examines the perceptions and attitudes of adolescent street girls of Harare Central Business District on commercial sex work and use of traditional medicine. As social actors, street adolescent girls construct and reinvent their childhood experiences around commercial sex work and use of traditional medicine. Some of the traditional medicines they use include guchu, makoko emabanana, mudzora, mushonga wejeko, mudiwa diwa, mugeza chibereko, mudzinga mhepo among others. However, from a child rights perspective, one could argue that use of these medicines contravenes principles of the UNCRC (1989) as they can expose these innocent adolescent girls to risks, abuse, exploitation and violence.

As the number of street children is increasing on the streets of Harare Central Business District, some of them are exposed to the use of traditional medicine. Previous studies by Bourdillon (1991, 1994a, 1994b, 2000), Mella (2012), Mhizha (2010), Ruparanganda (2008), Wakatama (2007), Chirwa and Wakatama (2000), Rurevo and Bourdillon (2003a and 2003b), Chirwa (2007), Dube (1997\& 1999) have failed to articulate the relationship between traditional medicine and commercial sex work among these children. One could argue that there is dearth of academic literature on commercial sex work and use of traditional medicine among adolescent street girls of Harare Central Business District. This study attempts to fill up this gap and encourage research in this direction.

\section{Conceptual Framework}

The child agency derived from new studies of childhood and child rights perspective is used to analyse the complex phenomena of commercial sex work and use of traditional medicine among adolescent street girls of Harare Central Business District. Scholars such as Giddens (1983 \& 1984), Turner (1991) observed that the structure agency theory conceptualises that behaviour which is as a result of either structure or the agency. In addition, the authors also noted that agency and structure work hand in hand as they are considered to be two sides of the same coins. Ritzer (1991) also observed that lying can also be considered as agency. 
The structure agency theory has been criticised for its failure to consider the level of vulnerability of disadvantaged children or citizens as noted by Ursin (2013). For example, there are people who might fail to demonstrate their agency as a result of increased level of vulnerability. In relation to adolescent street girls of Harare Central Business District, they demonstrated their agency through commercial sex work and also using various traditional medicines. One could argue that these adolescent girls manage to raise resources for survival through practices such as commercial sex work.

However, scholars such Bordonaro (2012), Bordonaro and Payne (2012) note that, agency becomes ambiguous as it clashed with moral and societal value system. In the context of adolescent street girls of Harare Central Business District, one could argue that from societal perspective they are expected to be asexual. At the same time Gigengack (2006) also observes that agency becomes self-destructive as it could lead to death. For example, one could argue that agency of these adolescent girls demonstrated in commercial sex work and use of traditional medicine could also lead to self-destruction.

\section{Child Rights Perspective}

The UNCRC (1989) defines child rights based on four principles namely, the best interest of the child, the right of a child to participation, non-discrimination and the right of a child to survival and development. Save the Children (2002) also notes that, child rights perspective recognises the relationship between the duty bearer and the rights holders. It can be argued that, it is a social contract that exists between the rights holders and the duty bearers.

The Government of Zimbabwe has ratified the UNCRC, ACRWC. A number of child rights laws, policies and programmes have been enacted or promulgated and these include, the Children's Act (5.06), Criminal Law (Codification and Reform) Act (9.23), The Zimbabwe National Orphan Care Policy of 1999, National Action Plan for Orphans and Other Vulnerable Children 2011 to 2015 among others. However, Okoli (2009) notes that the child rights perspective has been criticised for its Eurocentric orientation of childhood. For example, Bourdillon (2009) observes that child rights perspective could be regarded as romanticising childhood.

Within the context of adolescent, street girls who engage in commercial sex work and abuse of traditional medicines, one could argue that, the behaviours demonstrate huge child rights violations prevalent on the streets of Harare. One could add that the behaviours of commercial sex work and use of traditional medicines contravenes principles of child rights particularly 'the best interest of the child'. Within the context of national child rights laws, such adolescent girls are defined as 'children in 
need of care' by Children's Act (5.06) and as 'children in conflict with the law' by Criminal Law (Codification and Reform) Act (9.23).

\section{Methodology}

Convenience sampling was used to select research participants for this study. Neuman (2011) observed that this is advantageous as it becomes easier to select identify and recruit research participants through this method. A sample of six adolescent street girls participated in this study. The study respondents were drawn from the streets of Harare Central Business District. Additionally, the Harare Central Business District was also the research site of this study. The street ethnography and qualitative data collections such as, in-depth interviews, life history interviews, observation methods and informal conversations were used to collect data for this study. Scholars such as Van Dun (2014); Muchinako, Chokwaiva and Nyanguru (2012); De Melo Resend (2012); Klein (2011); Short and Hughes (2009) have also used street ethnography and qualitative data collection for studies involving street gangs and street drug trafficking and children. Brainer (2015); Veissiere (2010) observed that ethnographic studies provide opportunities for self-reflections among other advantages. Thematic content analysis was used to analyse findings of this study. Similarly, Bhattacharya and Nair's (2014) study used thematic content analysis. At the same time, scholars such as Mhizha (2010) and Ruparanganda (2008) also adopted the use of thematic content analysis on their studies with street dwelling children in Harare.

\section{The Use of Traditional Medicines}

Street adolescent girls who were practising commercial sex used a number of traditional medicines in their day to day lives. Some of the traditional medicines that were popular with street children included guchu, mudiwa diwa, mudonza nzeve, mushonga wejeko, mudzora among others. However, Ruparanganda (2008) observes that there could be side effects associated with the use of traditional medicines by these children. For example, some of the probable negative side effects of using these medicines could be over dose among others.

\section{Guchu}

The guchu concoction is one of the traditional medicines used by adolescent street children who trade in commercial sex work. During the field visits, the researcher observed that the street girls were using guchu concoction at one of the bases or mushika shika (places where they sell sex). On that particular day, the girls were sharing the concoction that was in a 2 litre ZLG mineral water bottle. One of the street girls indicated that, they use the concoction so as to prevent themselves from contracting sexually transmitted diseases. 
The perceptions and attitudes of adolescent street girls on the use of...

During life history interviews, one of the street girls revealed that, they use traditional medicines such as guchu, for improving their health well-being. She had this to say:

Isu nebasa redu rekukechesa kechesa, tino sangana nevanhu vakawanda, zvokuti dzimwe nguva, condomu rino tsemuka. Saka tinoshandisa guchu kucleaner system. Guchu ishasha mudhara nokuti, rakacheaper (Because of the kind our work of prostitution, we meet with many people to the extent that sometimes the condom may burst. So, we use guchu to clean our system. Guchu is good, elder because it is also cheap).

Plus patino kwirana nevarume, kuzasi uku kunenge kwechipinda mhepo, saka mhepo yacho, inozo rwadza mudumbu. Saka tino shandisa guchu kana mukina kuclean system yedu. (Plus when we have sex with men, our lower part of the body is exposed to air which may enter our system causing stomach pains. So, we use guchu or mukina to clean our system and prevent such pains).

In addition, during informal conversation, one of the street girls that trades sex at Njanji base revealed that, she used guchu to treat syphilis, one of the sexually transmitted diseases. She indicated that, she got the syphilis after having unprotected sex with one of her clients. She had this to say:

Mudhara, ndakambo batwa ne sick, ndakaipihwa nemumwe murume, ano shanda kuFawcett Security organisation. Handinyatso zivi kuti ndakaibatisa sei, asi ndinofunga kuti ndakaibatira mumwe musi watisina kushandisa macondomu chete. Ndakazoona after two weeks, ndavakuita iwe discharge yakakora. Ndakabvunza shamwari dzangu, dzikandikurudzira kushandisa guchu. Kubva zvanda shandisa guchu, ndava kunzwa zviri nani, discharge iya yakapera. (Elder, I contracted a sexually transmitted disease from a certain man working for Fawcett Security organisation. I do not know how I got it but I think I got it one of the days when we had unprotected sex. After two weeks, I noticed that I was passing on yellow and thick discharge from my vagina. I asked my friends who persuaded me to use guchu. After using guchu I felt better, the discharge has stopped).

Adolescent street girls of Harare Central Business District demonstrated their agency through commercial sex work. As a result of commercial sex work, they were able to raise resources for survival in a constraining super structure as noted by Giddens (1983 \& 1984). In other words, one could argue that, commercial sex work is one of the survival strategies of these adolescent street girls of Harare Central Business District. 
The use of traditional medicines such as guchu by street adolescent girls also demonstrates their human agency as they use locally available resources to their advantage in terms of improving their health and well-being. However, on the other hand Ruparanganda (2008) noted that the guchu concoction could have negative side effects to the users. Therefore, one becomes worried that the use of guchu by these 'children' could have long term effects on their reproductive health. Scholars such as Bordonaro (2012), Bordonaro and Payne (2012) also criticised such agency as 'ambiguous' since it clashes with societal values. One could argue that society does not expect children including those dwelling on the streets to engage in commercial sex work or any such related behaviours.

Gigengack (2006) criticised some of the notions associated with agency with street children. He observed self-destructive agency in the context of street children who abuse substances which lead to malnutrition or death. Related to commercial sex work and use of traditional medicine among adolescent street children of Harare Central Business District, we note notions of self-destructive agency as some of the long term effects associated with commercial sex work and use of traditional medicine could actually lead to death.

From a child's rights perspective, use of guchu by adolescent street girls to engage in commercial sex work illustrates child rights violations. Such behaviours contravene provision of the UNCRC (1989) particularly, article three which is the best interest of the child. Adolescent street children are defined as 'children in need of care' by Children's Act (5.06) and the NAP for OVCs (2011-2015) also refers to street children as vulnerable. Further, the Criminal Law (Codification and Reform) Act (9.23) also defines children who engage in commercial sex work as "children in conflict with the law'.

\section{Makoko emabanana (Banana peels)}

Makoko emabanana akapiswa (Smoked banana peels) were also used by adolescent street girls who practise commercial sex to treat syphilis and other sexually transmitted diseases. During in depth interviews, one of the street girls as a social actor admitted using the traditional medicine to treat sexually transmitted diseases. She had this to say:

Imi mudhara makambo ona Magunduru achishandisa macondom here? Manje nevarume vedu vemustreet ava, tinogara takabatwa nesick. Ini ndakambo batwa nayo yemaronda, ndika shandisa makoko emabanana akapiswa. (Elder, have you ever seen Magunduru using condoms? So, with our men of the street, we are always contracting sexually transmitted 
diseases. Once I contracted syphilis and I used the ashes of burnt and smoked banana peels as treatment).

The use of traditional medicines such as makoko emabanana (Banana peels) for treatment of sexually transmitted diseases demonstrate human agency (Giddens, 1984), where, probably these children have limited access to modern medicine. The use of the traditional medicine could be the only available options for these children. Scholars like Ruparanganda (2008) observe that street children in Harare resort to use of traditional medicine partly because they faced stigma and discrimination. He adds that they are stigmatised as people of no fixed abode in some of the hospitals such as Harare Central Hospital. There are a number of health risks as some of these medicines may not be effective.

From a child rights perspective, duty bearers in the name of Government of Zimbabwe and other key stakeholders should provide health services to adolescent street girls. Additionally, for street girls to be exposed to the risks associated with commercial sex work such as sexually transmitted diseases, it demonstrates that the duty bearer is not providing enough protection services to these children.

\section{Mudzora}

Another concoction used is called mudzora. During informal conversations, one of the street girls confessed that they also use mudzora to tighten their vulva. It was revealed that commercial sex work practices was enshrined on male clients preferring girls with tighter vulva. One respondent, submitted that after realising that, from using the medicine to make her vulva tight, she was able to attract a swarm of clients. She had this to say:

Ndino shandisa mudzora, unodzora kuzasi kwedu. Nokuzvara, kuzasi $k w e d u$ kunodhamba mudhara. Mhene dzinoda vakadzi vane $b^{* * *}$ rinobata $m^{* * * *}$. Plus nebasa redu iri kuti zvifambe, ndinoshandisa mudzora pandinogeza pose. Dzimwe nguva ndino pfekera powder yacho $m u^{* * *}$. (I use mudzora to tighten my vagina. As a result of giving birth, the vulva gets loose, elder. Rich clients like women with tight vulva. Plus, given our work, we use the medicine such that it goes well with you. Sometimes I put the powder inside my vagina).

The girl also revealed that, she bought some of the traditional medicine on the street corners and also from Mupedzanhamo Mbare area. She revealed that the majority of the street corners of Harare Central Business District were awash with the traditional medicine. 
The use of mudzora by adolescent street girls in Harare's CBD to facilitate commercial sex work demonstrate agency of these children. Their agency is also illustrated by the knowledge and skills of using the traditional medicine to contract their vulva. The agency is also demonstrated through their ability to use the already available opportunities and resources to their advantage. However, mudzora, used by adolescent girls could negatively affect some of the users as it exposes them to infections and diseases such as cervix cancer among others. Ruparanganda (2008) observed that such concoctions could lead to dry sex, which worsen the increased vulnerability to sexual transmitted diseases including HIV and AIDS. Use of mudzora contravenes the provisions of the child rights principles as well as adolescent girls continue to project themselves to the sexual world at very tender age situations which could pose challenges when they mature.

\section{Mushonga weJeko}

Apart from using mudzora, the street girls also use mushonga wejeko. Mushonga wejeko is used as relief in cases where the girls have problems related to period pains. The study noted that, the girls would put the medicine in warm water and then drink it. The girls revealed that they buy the medicine from street corners. A sachet of mushonga wejeko was reported to costing $\$ 1$. Street girls narrated that they use the medicine for period pains problems. One girl said:

Ini ndino shandisa mushonga wejeko, uno ndibatsira pamaperiod pains. Saka ndikashandisa mushonga wejeko zvinoita nane. Dambudziko riripo ndere kuti nemushonga uyu shamwari yangu yazombo buda ropa rakawanda, akazoenda kuchipatara. Plus uno kwanisa kuenda kumwedzi kaviri kana kakawanda paone month. (I use the traditional medicine of jeko, it assists me on period pains. So, If I use the medicine it gets better. The problem which is there with this medicine is that my friend had excessive bleed and she ended up visiting the hospital. Plus you can have several menstrual sessions on single month).

During fieldwork visits, one of the vendors confirmed that a sizeable number of people were buying his merchandise, including street girls. The use of traditional medicine such as mushonga wejeko by street girls demonstrates that the girls as active agents who exploit a number of resources to their advantage.

\section{Mudiwa diwa kana Mushonga wemaLuck}

The study also noted that, street girls use a number of traditional medicines such as mudiwa diwa kana mushonga wemaluck. Mudiwa diwa is also known as gwezvo. One of the girls revealed that, if she does not use such kind of medicines, it becomes extremely difficult for her to attract clients. She had this to say: 
The perceptions and attitudes of adolescent street girls on the use of...

Pamushika shika wechihure pano, pano netsa mudhara. Vasikana vamunoona ava vano mhanyirwa nevarume, vano shandisa mishonga wemudiwa diwa. Vanoita mari yakawanda imi makangoti vavava. Kudiwa nevarume, hakusi kunaka chete unoto shandisa mushonga wekudhonza varume. Mudiwa diwa unoiswa mumafuta ako ekuzora. (When you are at this place, where we compete for clients, it is not easy. The ladies that you see here, they are on demand by male clients because the use traditional medicine mudiwa diwa. They make a lot of money when you are doing nothing. To be liked my males is not about beautiful only but you use medicine so as to attract them. Mudiwa diwa is put on the cream which you use for smearing).

Honayi vamwe, vasikana vakanaka chaizvo asi hava wani maclients wani? Asi aya masenior anoshandisa mushonga, varume havaperi. Mishonga iyi inowanikwa kuMbare kana kuzvichembere zvinogara kuEpworth, Mufakose nokuma high density mazhinji. (Just look, some ladies are very beautiful but why don't have clients? But those seniors who use medicines have a lot of clients. These medicines are found in Mbare or from elderly people who stay in Epworth, Mufakose among other high density areas).

Vamwevo vasikana vanotoshandirwa kumasowe kuti vawane maclients wani mudhara, pakaipa apa mudhara. Hazvisi zvinhu zvokutamba nazvo, inyanya yemari ka. (Some of the girls they consult apostolic faith sect, so as to get more clients, elder. There are no jokes in such issues; there is money at stake here).

As social actors, the adolescent street girls used traditional medicine mudiwa diwa kana gwezvo kana mushonga weluck. The use of the traditional medicine illustrates agency of these children as through using the charm they were able to lure more clients. At the same time, the agency is also demonstrated as they knew that through luring more clients would translate to increased opportunities for income. These mechanisms further expose these girls to all the dangers of sexual indulgencies.

\section{Mugeza Chibereko}

Street girls in Harare CBD also use mugeza chibereko among other traditional medicines. During informal conversations, one of the street girls narrated that as an active agent, she uses the medicines for cleansing her uterus. She revealed that as a result of practising commercial sex work, she is increasingly exposed to a number of infections or diseases. Therefore, she would use such medicines to cleanse her uterus. She had this to say: 
Nebasa redu iri rekukechesa, unosangana netsvina dzakawanda, pamwe condom rino putika, saka uno fanirwa kushandisa mushonga wakafanana nemugeza chibereko, kubvisa tsvina dzose. Ndinoisa mushonga иуи ти $300 \mathrm{ml}$ remineral water, ndobva ndanwa kwemazuva matatu. (In this sex work, we experience a lot of dirty stuff. Sometimes condoms busts, so you need to use traditional medicine such as mugeza chibereko to cleanse yourself. I put the medicine on a $300 \mathrm{ml}$ container of mineral water then I drink the concoction for three days).

The use of mugeza wechibereko by adolescent street girls to cleanse their uterus illustrates agency of these children. The agency is expressed in their knowledge and skills that the medicine could improve their health.

\section{Mudzinga mhepo}

Adolescent street children of Harare CBD use mudzinga mhepo to remove bad luck. One indicated that:

Ne basa rekukechesa redu iri, uno fanirwa kushandisa mushonga wekudzinga mhepo, kuti zvikufambirevo uwane mari sevamwe vasikana. (This commercial sex work of ours, you need to use medicine to remove evil spirits such that you get money like any other commercial sex worker).

One of the gate keepers, a former employee of Streets Ahead, also confirmed that, adolescent street girls use a variety of traditional medicines such as mudzora, mudhonza nzeve, mushonga wejeko, guchu, mudiwa diwa, mudzinga mhepo, among others. She added that some of the medicines are sold from the street corners and from sangomas in high density areas such as Mbare, Mufakose, and Epworth among others.

From the submissions above, it is noted that adolescent girls in Harare CBD appears to have accepted their fate and the only way to eke out a living is to sell sex. The world of commercial sex work has exposed them to various ways of manoeuvring and surviving the challenges as well as demands of commercial sex work. A variety of concoctions most of which are readily available and cheaply accessed in the streets are used for a variety of reasons. More importantly, there is an effort among the adolescent girls to safeguard their healthy and protect themselves from any possible health risks. But given the fact that a number of children rights are contravened, the adolescent girls remain gravely exposed to various health dangers, physically, socially, psychologically and economically. 


\section{Conclusion}

In conclusion, adolescent street girls in Harare CBD perceive that there is a relationship between commercial sex work and use of traditional medicine. As social actors these children construct and reconstruct their childhood around traditional medicine and commercial sex work. As discussed above, the adolescent street girls use a number of traditional medicines such as mudzora, mushonga wejeko, mudiwa diwa, mudzinga mhepo, mudhonza nzeve among others. Ostensibly, some scholars such as Bordonaro (2012), Bordonaro and Payne (2012) have queried such agency as it clashes with societal values. Gigengack (2006) has also criticised similar agency noting that they are self-destructive. However, from a child rights perspective, one could argue that, commercial sex work and the use of traditional medicine exposed the adolescent street children to sexual abuse, violence and exploitation. The Government of Zimbabwe is called upon as the primary duty bearer to provide more protection services to these children in order to reduce their levels of vulnerability.

\section{REFERENCES}

African Union 1999. African Charter on the Rights and Welfare of Children, Addis Ababa

Bhattacharya, A. and Nair, R. 2014. Girls on the street: Their life experiences and vulnerability to sexual abuse, The Indian Journal of Social Work 75 (1): 33- 48

Brainer, A. 2015. Mothering gender and sexually non confirming children in Taiwan Journal of Family Issues 1-27, DOI: 10.1177/0192513X15598549

Bordonaro, L. 2012. Agency does not mean freedom. Cape Verdean street children and the politics of children's agency Children's Geographies 10 (4): 413-426

Bordonaro, L. and Payne, R. 2012. Ambiguous agency: Critical perspectives on social intervention with children and youth in Africa Children's Geographies 10(4): 365- 372.

Bourdillon, M.F.C 1991. Poor, harassed but very much alive: An account of street people and their organization Gweru: Mambo Press.

Bourdillon, M.F.C 1994a. Street Children in Harare Africa, Journal of the International African Institute, 4 (4): 516-533

Bourdillon, M.F.C 1994b. Street Children in Harare Africa, Journal of the International African Institute, 4 (4): 516-533. 
Witness Chikoko, Victor Muzvidziwa, Watch Ruparanganda \& Emelia Chikoko

Bourdillon, M.F.C (ed.) 2000. Earning a life: Working Children in Zimbabwe, Harare, Weaver Press.

Chirwa, Y. 2007. Children, Youth and Economic Reforms, An Expedition of the State of Street Children in Zimbabwe, In Maphosa, F. Kujinga, K. \& Chingarande, S. D. (eds). Zimbabwe's Development Experiences since 1980, Challenges and Prospects for the Future, 76-93, OSSREA, Ethiopia

Chirwa, Y. and Wakatama, M. (2000) Working street children in Harare, In Bourdillon (eds.) Earning a life: Working Children in Zimbabwe, Harare: Weaver Press.

De Melo Resend, V. 2012. Critical discourse analysis and ethnography: The crisis in the national street children's movement in Brazil, Qualitative Research 13 (5): 511 527.

Dube, L. 1997. AIDS-risk patterns and Knowledge of the Disease among Street Children in Harare, Zimbabwe; Journal of Social Development in Africa, 12(2): 61-73.

Dube, L. 1999. Street Children: A part of organized society, (Unpublished D.Phil. Thesis), Department of Sociology, University of Zimbabwe, Harare

Giddens, A. 1983. Sociology: Second Edition, Oxford: Black Publishers.

Giddens, A. 1984. The Constitution of Society: Outline of the Theory of Structuration, Los Angeles: University of California Press.

Gigengack, R. 2006. Young, Damned and Banda: The world of Young Street People in Mexican City, 1990-1997, (Unpublished D.Phil. Thesis), Amsterdam: University of Amsterdam.

Government of Zimbabwe 2001. The Children's Act (5.06), Harare: Government Printers,

Government of Zimbabwe 2006. The Criminal Codification and Reform Act (9.23) Harare: Government Printers.

Government of Zimbabwe 2010. National Action Plan for Orphans and Other Vulnerable Children 2011- 2015, Harare: Government Printers.

Klein, M. W. 2011. Who can you believe? Complexities of international street gang research International Criminal Justice Review 21 (3): 197-207

Mhizha, S. 2010. The self-image of adolescent street children in Harare, (Unpublished M.Phil. Thesis), Department of Psychology, Harare: University of Zimbabwe. 
Muchinako, G. A., Chikwaiva, B. K. and Nyanguru, A. (2013) Children living and or working on the streets in Harare: Issues and challenges Journal of Social Development in Africa 28 (2) pp.93-112.

Ritzer, G. 1992. Sociological Theory, Third Edition, New York: McGraw-Hill.

Rurevo, R. and Bourdillon, M.F.C 2003a. Girls: The Less Visible Street Children of Zimbabwe, Children, Youth and Environment, 13(1):1-20

Rurevo, R. and Bourdillon, M.F.C (2003b) Girls on the street, Harare: Weaver Press.

Ruparanganda, W. 2008. The Sexual Behaviour Patterns of Street Youth of Harare, Zimbabwe, in the Era of the HIV and AIDS pandemic, (Unpublished D.Phil. Thesis), Sociology Department, Harare: University of Zimbabwe.

Turner, J. 1991. The structure of sociological theory, California: Wadsworth Publishing Company.

Neuman. W. L. 2011. Social Research Methods, Qualitative and Quantitative Approaches New York: Pearson.

Short, J. F. and Hughes, L. A. 2009. Urban ethnography and research integrity: Emperial and theoretical dimensions, Ethnography 10 (4): 397- 415.

Ursin, M. 2013. The place where I buried my bellybutton'- a longitudinal study of transitions and belonging among young men on the street in Salvador, Brazil, (Unpublished PhD Thesis), Faculty of Social Sciences, University of Nordland.

United Nations 1989. The United Nations Convention on the Rights of a Child, Geneva.

Van Dun, M. 2014. "It's never a sure deal": Drug trafficking, violence and coping strategies in a Peruvian cocaine enclave (2003- 2007) Journal of Drug Issues 44 (2): 180-196.

Veissiere, S. P. L. 2010. Making a living: The Gringo ethnographer as pimping of the suffering in the late Capitalist night Cultural Studies-Critical Methodologies 10 (1): 29- 39 . 